\title{
Targeting exosites on blood coagulation proteases
}

\author{
ROBSON Q. MONTEIRO \\ Laboratório de Hemostase e Venenos, Instituto de Bioquímica Médica, Programa de Biologia Estrutural \\ Centro de Ciências da Saúde, Universidade Federal do Rio de Janeiro, Av. Bauhínia 400, Ilha do Fundão \\ 21941-590 Rio de Janeiro, RJ, Brasil
}

Manuscript received on December 27, 2004; accepted for publication on January 18, 2005; presented by Lucia Mendonça Previato

\begin{abstract}
The high specificity of blood coagulation proteases has been attributed not only to residues surrounding the active site but also to other surface domains that are involved in recognizing and interacting with macromolecular substrates and inhibitors. Specific blood coagulation inhibitors obtained from exogenous sources such as blood sucking salivary glands and snake venoms have been identified. Some of these inhibitors interact with exosites on coagulation enzymes. Two examples are discussed in this short revision. Bothrojaracin is a snake venom-derived protein that binds to thrombin exosites 1 and 2. Complex formation impairs several exosite-dependent activities of thrombin including fibrinogen cleavage and platelet activation. Bothrojaracin also interacts with proexosite 1 on prothrombin thus decreasing the zymogen activation by the prothrombinase complex (FXa/FVa). Ixolaris is a two Kunitz tick salivary gland inhibitor, that is homologous to tissue factor pathway inhibitor. Recently it was demonstrated that ixolaris binds to heparin-binding exosite of FXa, thus impairing the recognition of prothrombin by the enzyme. In addition, ixolaris interacts with FX possibly through the heparin-binding proexosite. Differently from FX, the ixolaris-FX complex is not recognized as substrate by the intrinsic tenase complex (FIXa/FVIIIa). We conclude that these inhibitors may serve as tools for the study of coagulation exosites as well as prototypes for new anticoagulant drugs.
\end{abstract}

Key words: blood coagulation, serine proteases, exosites, exogenous inhibitors.

\section{INTRODUCTION}

The coagulation cascade is usually defined as a series of sequential proteolytic reactions in which blood-circulating zymogens or cofactor precursors are converted to active enzymes and active cofactors, respectively (Figure 1). Under physiological situations, coagulation is restricted to the vessel damage area and results from the activities of procoagulant enzymatic complexes that assemble on the sites provided by the subendothelial matrix and peripheral blood cells. These surface-associated complexes are

Correspondence to: Robson Q. Monteiro

E-mail: robsonqm@bioqmed.ufrj.br composed by a serine protease, a nonenzymatic cofactor protein, calcium ions and the cellular membrane component (Mann 1999). The catalytic domains of the serine proteinases of coagulation are highly homologous to each other as well as to trypsin (Rose and Di Cera 2002). Despite these similarities, coagulation proteinases act on their protein substrates with narrow and distinctive specificity (Bode et al. 1997). Although it is assumed that protein substrate specificity arises from specific binding interactions between the active site of the enzyme and distinctive amino acid residues surrounding the scissile bond, specific protein substrate recognition 
through extended macromolecular interaction sites (exosites) has been documented (Fenton et al. 1988, Krishnaswamy 2005). Exosite dependent substrate recognition implies that extended surfaces on the enzyme complex, distinct from residues surrounding the catalytic site, contribute to substrate affinity by favouring productive interactions between enzyme and substrate. The existence of extended surfaces appears to be the rule rather than the exception in blood coagulation factors. In fact, structural and functional studies have characterized exosites in thrombin (Bode et al. 1989, Sheehan and Sadler 1994), Factor Xa (FXa) (Rezaie 2000), FIXa (Yang et al. 2002), and FVIIa/tissue factor complex (Banner et al. 1996).

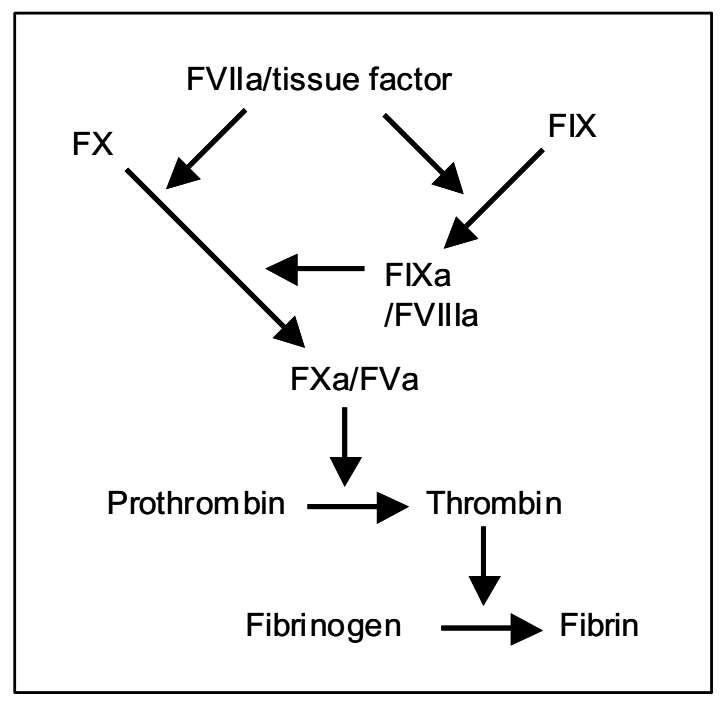

Fig. 1 - Simplified scheme of blood coagulation reactions. Exposure of tissue factor upon vascular damage leads to complex formation with FVIIa (extrinsic tenase complex). FIX and FX are subsequently activated. FIXa combines with the protein cofactor FVIIIa to form the intrinsic tenase complex that efficiently activates FX. FXa combines with the protein cofactor FVa to form the prothrombinase complex, which activates prothrombin into thrombin.

Specific blood coagulation inhibitors from exogenous sources such as blood sucking salivary glands and snake venoms have been identified (Ribeiro and Francischetti 2003, Markland 1998). Two of these inhibitors target coagulation factor exosites. The present review will focus on some of these inhibitors, describing their mechanisms of action. Of particular interest is the possibility of using these molecules as tools for the study of coagulation exosites as well as prototypes for new anticoagulant drugs.

\section{PROTHROMBIN AND THROMBIN}

Thrombin is formed by the cleavage of two peptide bonds in prothrombin by blood coagulation factor Xa. A significant increase in activation is observed upon calcium-dependent binding of FXa to membranes containing acidic phospholipids and maximum activity requires further interaction with the protein cofactor, FVa, which leads to formation of the prothrombinase complex (Rosing et al. 1980). Therefore, it is assumed that phospholipids decrease the $\mathrm{Km}$ for prothrombin by a factor of $\sim 100$ while factor Va increases the Kcat by a factor of $\sim 3000$, resulting in $\mathrm{a} \sim 10^{5}$-fold increase in the catalytic efficiency of the prothrombinase complex compared to factor Xa alone.

During prothrombin activation, besides the exposure of the catalytic site, additional regulatory domains become available. The crystallographic structure of $\alpha$-thrombin revealed two positively charged regions on the enzyme surface, the anion-binding exosites 1 and 2, which are located at a certain distance from the catalytic site (Bode et al. 1989). Anion-binding exosite 1 interacts with fibrinogen, the platelet thrombin receptor PAR-I, thrombomodulin, heparin cofactor II, and factors V and Va. The thrombin exosite 2 is located above the active site pocket and is referred to as the heparin-binding site (Sheehan and Sadler 1994).

The C-terminal portion of hirudin, a leechderived inhibitor, was the first demonstrated exosite inhibitor (Naski et al. 1990), and determination of the crystal structure of the thrombin-hirudin complex showed that this interaction is mediated by a number of ionic and hydrophobic interactions. Interaction of $\mathrm{C}$-terminal hirudin with thrombin exosite 1 does not block the enzyme catalytic activity. Rather, the ability of the enzyme to cleave small syn- 
thetic peptides may be increased (Liu et al. 1991). On the other hand, recognition of macromolecular substrates is severely impaired (Krstenansky and Mao 1987).

Bothrojaracin (BJC) was isolated from the venom of the Brazilian snake jararaca (Bothrops jararaca $)$ and belongs to the C-type $\left(\mathrm{Ca}^{2+}\right.$. dependent) lectin-like related protein family (Zingali et al. 1993). BJC has been characterized as a potent and selective thrombin inhibitor $\left(K_{D}=\right.$ $0.7 \mathrm{nM})$ since it binds to both thrombin exosites (Arocas et al. 1996). As seem with C-terminal hirudin, Bothrojaracin interaction with thrombin exosite 1 allosterically modulates the cleavage of synthetic substrates (Monteiro et al. 1999) by the enzyme while the cleavage of macromolecular substrates is strongly inhibited (Zingali et al. 1993).

Recent studies showed that the thrombin exosite 1 is partially exposed on prothrombin as a precursor state (proexosite 1 ) displaying a $\sim 100$-fold lower affinity for hirudin peptides (Anderson et al. 2000a). Therefore, proexosite 1 consists in a binding site for FVa (Chen et al. 2003), and the interaction with $\mathrm{C}$-terminal hirudin decreases the productive recognition of prothrombin as substrate by FXa in the presence but not in the absence of its protein cofactor (Anderson et al. 2000b).

Remarkably, BJC may also bind to proexosite $1\left(K_{D}=75 \mathrm{nM}\right)$, although exhibiting a $\sim 100$-fold higher affinity than C-terminal hirudin (Monteiro et al. 2001). Data obtained in our laboratory also showed that BJC decreases prothrombin activation by FXa in the presence but not in the absence of FVa (Monteiro and Zingali 2002). At this point, results obtained with human platelets suggest that proexosite 1 may play an important role in the physiological activation of prothrombin and may be a potential target for the development of new antithrombotic drugs.

\section{FACTOR X AND FACTOR Xa}

Ixolaris is a novel recombinant two Kunitz tick salivary gland inhibitor that is homologous to a physio- logical plasma inhibitor named tissue factor pathway inhibitor (TFPI) (Francischetti et al. 2002). Similarly to TFPI, ixolaris is a potent inhibitor of the extrinsic tenase complex (FVIIa/tissue factor). It interacts with FXa and further binds to FVIIa/tissue factor, thus resulting in a quaternary complex in which the catalytic site of FVIIa is inactive. Thus, the extrinsic tenase complex is no longer able to activate FX and FIX. However, in contrast to human TFPI, ixolaris tightly binds to zymogen FX and to the catalytic site occupied DEGR FXa, indicating that exosites are involved in $\mathrm{FX}(\mathrm{a}) /$ ixolaris interaction.

Determination of the crystal structure of FXa indicates that 7 of the 11 basic residues that comprise the thrombin exosite 2 are conserved at the same or similar three dimensional locations (Padmanabhan et al. 1993). Recent site directed mutagenesis studies have indicated that the basic residues Arg-93, Lys-96, Arg-125, Arg-165, Lys-169, Lys-236, and Arg-240 constitute an exosite in the heavy chain of FXa and that this region can effectively bind heparin (Rezaie 2000). Moreover, residues Arg-165 and Lys-169 seem to play a key role in FVa and/or prothrombin recognition by the enzyme in the prothrombinase complex (Rezaie 2000).

In fact, ixolaris was recently characterized as the first inhibitor to date that specifically binds to FXa heparin-binding exosite (Monteiro et al. 2005). This interaction also results in a decrease in the productive recognition of prothrombin as substrate by FXa either in the absence or in the presence of FVa. Also, the recognition of prothrombin by the prothrombinase complex is greatly affected.

Interestingly, as seem with thrombin exosite 1, the FXa heparin-binding exosite seems to be in a precursor state in FX, consisting in a recognition site for the protein cofactor FVIIIa (Nogami et al. 2004). Complex formation between ixolaris and FX strongly decreases the zymogen activation by the intrinsic tenase complex (FIXa/FVIIIa). At this point we believe that ixolaris impairs FX-FVIIIa interactions thus decreasing the productive recognition of the zymogen as substrate by the intrinsic tenase complex (unpublished results). 
TABLE I

Two examples of exosite inhibitors.

\begin{tabular}{c|c|c|c|c}
\hline Inhibitor & Source & Target & Binding-site & Consequence \\
\hline Bothrojaracin & $\begin{array}{c}\text { Bothrops jararaca } \\
\text { venom }\end{array}$ & Thrombin & $\begin{array}{c}\text { Exosite 1 and } \\
\text { exosite } 2\end{array}$ & $\begin{array}{c}\text { Inhibition of fibrinogen clotting and } \\
\text { platelet aggregation }\end{array}$ \\
\hline Ixolaris & $\begin{array}{c}\text { Ixodes scapularis } \\
\text { salivary gland }\end{array}$ & FXa & $\begin{array}{c}\text { Heparin-binding } \\
\text { exosite }\end{array}$ & $\begin{array}{c}\text { Inhibition of prothrombin activation } \\
\text { by prothrombinase complex }\end{array}$ \\
\hline & & FX & $\begin{array}{c}\text { Heparin-binding } \\
\text { proexosite }\end{array}$ & $\begin{array}{c}\text { Inhibition of FX activation by } \\
\text { intrinsic tenase complex }\end{array}$ \\
\hline
\end{tabular}

Therefore, ixolaris exhibits a unique mechanism of action in which all procoagulant complexes of the blood coagulation cascade are being inhibited. This molecule may be used as a tool to study FXa heparin-binding exosite as well as FX heparinbinding proexosite. It may also help to develop new anticoagulants targeting both FX and FXa.

\section{CONCLUSION}

Exogenous inhibitors of blood coagulation may exhibit distinctive mechanisms of action. Bothrojaracin, a (pro)thrombin ligand from snake-venom and ixolaris, a FX(a) ligand from tick salivary gland, give two examples of such specific inhibitors. Since these proteins target both the active enzymes and their respective zymogens, they display more than one mechanism to impair blood coagulation. Remarkably they recognize regions in the active enzymes that are remote from the active site (exosites) but play key roles in the macromolecular substrate recognition. On the other hand, these exosites are found in precursor states (proexosites) in prothrombin and FX, being involved in the zymogen activation. Bothrojaracin and ixolaris recognize proexosites and impair zymogen activation. The in vivo properties of both inhibitors are now under investigation in order to determinate their abilities as antithrombotic drugs.

\section{ACKNOWLEDGMENTS}

The author would like to thank the financial support given by Fundação Chagas Filho de Amparo à Pesquisa do Rio de Janeiro (FAPERJ), Conselho Nacional de Desenvolvimento Científico e Tecnológico (CNPq), and Programa de Apoio a Núcleos de Excelência (PRONEX). This work was also supported by a grant from " Programa Interinstitucional de Ensino, Pesquisa e Extensão em Biologia do Câncer' by Fundação Ary Frauzino para Pesquisa e Controle do Câncer (FAF) and Fundação Educacional Charles Darwin (FECD).

\section{RESUMO}

A alta especificidade das proteases da coagulação tem sido atribuída não somente aos resíduos que cercam o sítio ativo, mas também a outros domínios de superfície que estão envolvidos no reconhecimento e interação com substratos macromoleculares e inibidores. Inibidores específicos da coagulação sanguínea obtidos de fontes exógenas como glândulas salivares de animais hematófagos e venenos de serpentes têm sido identificados. Alguns desses inibidores interagem com os exosítios das enzimas da coagulação. Dois exemplos são discutidos nesta curta revisão. A Botrojaracina é uma proteína derivada de veneno de serpente que se liga aos exosítios 1 e 2 da trombina. A formação do complexo impede várias atividades da trombina dependentes do exosítio 1 incluindo a clivagem do fibrinogênio e a ativação plaquetária. A Botrojaracina também interage com o proexosítio 1 da protrombina diminuindo a ativação do zimogênio pelo 
complexo protrombinase (FXa/FVa). O ixolaris é um inibidor com dois domínios Kunitz obtido da glândula salivar de carrapato, homólogo ao inibidor da via do fator tecidual. Recentemente foi demonstrado que o ixolaris se liga ao exosítio de ligação à heparina do FXa, impedindo o reconhecimento da protrombina pela enzima. Além disso, o ixolaris interage com o FX, possivelmente através do proexosítio de ligação à heparina. Diferentemente do FX, o complexo ixolaris-FX não é reconhecido como substrato pelo complexo tenase intrínseco (FIXa/FVIIIa). Nós concluimos que esses inibidores podem servir como ferramentas para o estudo dos exosítios da coagulação, assim como protótipos para novas drogas anticoagulantes.

Palavras-chave: coagulação sanguínea, serino-proteases, exosítios, inibidores exógenos.

\section{REFERENCES}

Anderson PJ, Nesset A, Dharmawardana KR and Bock PE. 2000a. Characterization of proexosite I on prothrombin. J Biol Chem 275: 16428-16434.

Anderson PJ, Nesset A, Dharmawardana KR and Bock PE. 2000b. Role of proexosite I in factor Vadependent substrate interactions of prothrombin activation. J Biol Chem 275: 16435-16442.

Arocas V, Zingali RB, Guillin MC, Bon C and JanDROT-PERRUS M. 1996. Bothrojaracin: a potent twosite-directed thrombin inhibitor. Biochemistry 35 : 9083-9089.

Banner DW, D'Arcy A, Chene C, Winkler FK, Guha A, Konigsberg WH, Nemerson Y and KirchHOFER D. 1996. The crystal structure of the complex of blood coagulation factor VIIa with soluble tissue factor. Nature 380: 41-46.

Bode W, Mayr I, Baumann U, Huber R, Stone SR AND Hofsteenge J. 1989. The refined 1.9 A crystal structure of human-thrombin: interaction with D Phe Pro Arg chloromethylketone and significance of the Tyr Pro Pro Trp insertion segment. EMBO J 8: 3467-3475.

Bode W, Brandstetter H, Mather T and Stubbs MT. 1997. Comparative analysis of haemostatic proteinases: structural aspects of thrombin, factor Xa, factor IXa and protein C. Thromb Haemost 78 : 501-511.

Chen L, Yang L and Rezaie AR. 2003. Proexosite-1 on prothrombin is a factor Va-dependent recognition site for the prothrombinase complex. J Biol Chem 278: 27564-27569.

Fenton JW 2ND, OLSON TA, ZABINSKi MP AND WiLnER GD. 1988. Anion-binding exosite of human alphathrombin and fibrin(ogen) recognition. Biochemistry 27: 7106-7112.

Francischetti IM, Valenzuela JG, Andersen JF, Mather TN ANd Ribeiro JM. 2002. Ixolaris, a novel recombinant tissue factor pathway inhibitor (TFPI) from the salivary gland of the tick, Ixodes scapularis: identification of factor $\mathrm{X}$ and factor $\mathrm{Xa}$ as scaffolds for the inhibition of factor VIIa/tissue factor complex. Blood 99: 3602-3612.

KrishnaSWAMY S. 2005. Exosite-driven substrate specificity and function in coagulation. J Thromb Haemost 3: 54-67.

Krstenansky JL and Mao SJT. 1987. Antithrombin properties of $\mathrm{C}$-terminus of hirudin using synthetic unsulfated N-alpha-acetyl-hirudin45-65. FEBS Lett 211: $10-16$.

Liu LW, Vu TKH, Esmon CT and Coughlin SR. 1991. The region of the thrombin receptor resembling hirudin binds to thrombin and alters enzyme specificity. J Biol Chem 266: 16977-16980.

MANN KG. 1999. Biochemistry and physiology of blood coagulation. Thromb Haemost 82: 165-174.

MARKLAND FS. 1998. Snake venoms and the hemostatic system. Toxicon 36: 1749-1800.

Monteiro RQ AND Zingali RB. 2002. Bothrojaracin, a proexosite I ligand, inhibits factor Va-accelerated prothrombin activation. Thromb Haemost 87: 288293.

Monteiro RQ, Raposo JG, Wisner A, Guimaraes JA, Bon C and Zingali RB. 1999. Allosteric changes of thrombin catalytic site induced by interaction of bothrojaracin with anion-binding exosites I and II. Biochem Biophys Res Commun 262: 819-822.

Monteiro RQ, Bock PE, Bianconi ML AND ZINGALI RB. 2001. Characterization of bothrojaracin interaction with human prothrombin. Protein Sci 10: 1897-1904.

Monteiro RQ, Rezaie AR, Ribeiro JMC and FranCISCHETTI IM. 2005. Ixolaris: a factor Xa heparinbinding exosite inhibitor. Biochem $\mathrm{J}$ (in press).

Naski MC, Fenton JW 2nd, Maraganore JM, OlSON ST AND SHAFER JA. 1990. The COOH-terminal 
domain of hirudin. An exosite-directed competitive inhibitor of the action of alpha-thrombin on fibrinogen. J Biol Chem 265: 13484-13489.

Nogami K, Freas J, Manithody C, Wakabayashi H, RezaIe AR and Fay PJ. 2004. Mechanisms of interactions of factor $\mathrm{X}$ and factor $\mathrm{Xa}$ with the acidic region in the factor VIII A1 domain. J Biol Chem 279: 33104-33113.

Padmanabhan K, Padmanabhan KP, Tulinsky A, Park CH, Bode W, Huber R, Blankenship DT, Cardin AD and Kisiel W. 1993. Structure of human des(1-45) factor Xa at 2.2 A resolution. J Mol Biol 232: 947-996.

REZAIE AR. 2000. Identification of basic residues in the heparin binding exosite of factor Xa critical for heparin and factor Va binding. J Biol Chem 275: 3320-3327.

Ribeiro JMC and Francischetti IMB. 2003. Role of arthropod saliva in blood feeding: sialome and post sialome perspectives. Ann Rev Entomol 48: 73-88.
Rose T and Di Cera E. 2002. Substrate recognition drives the evolution of serine proteases. J Biol Chem 277: 19243-19246.

Rosing J, Tans G, Govers Riemslag JW, Zwaal RF AND Hemker HC. 1980. The role of phospholipids and factor $\mathrm{Va}$ in the prothrombinase complex. J Biol Chem 25: 274-283.

Sheehan JP AND SadLer JE. 1994. Molecular mapping of the heparin binding exosite of thrombin. Proc Natl Acad Sci USA 91: 5518-5522.

Yang L, Manithody C and Rezaie AR. 2002. Localization of the heparin binding exosite of factor IXa. J Biol Chem 272: 50756-50760.

Zingali RB, Jandrot-Perrus M, Guillin MC and BoN C. 1993. Bothrojaracin, a new thrombin inhibitor isolated from Bothrops jararaca venom: characterization and mechanism of thrombin inhibition. Biochemistry 32: 10794-10802. 